\title{
PEMANFAATAN AMPAS TEBU DAN KULIT PISANG DALAM PEMBUATAN KERTAS SERAT CAMPURAN
}

\author{
Allita Yosephine, Victor Gala, Aning Ayucitra ${ }^{1 *}$, Ery Susiany Retnoningtyas ${ }^{2}$ \\ ${ }^{1}$ Kelompok Keahlian Rekayasa Proses \\ 2Kelompok Keahlian Teknologi Bioproses \\ Jurusan Teknik Kimia, Fakultas Teknik, Universitas Katolik Widya Mandala \\ Jalan Kalijudan 37, Surabaya 60114 \\ E-mail: aayucitra@yahoo.com
}

\begin{abstract}
Abstrak
Kertas serat campuran (atau kertas komposit) merupakan kertas yang terbuat dari dua jenis serat berbeda yang bertujuan untuk memperkuat kertas tersebut. Dalam penelitian ini, pulp ampas tebu dan pulp kertas koran bekas digunakan untuk membuat kertas serat campuran dengan tujuan aplikasi kertas kemasan. Sebagai binder, digunakan kulit pisang yang mengandung pati dan serat. Tujuan penelitian ini adalah untuk mempelajari komposisi pulp ampas tebu dan pulp kertas koran, serta untuk mengetahui massa binder yang digunakan agar dihasilkan kertas serat campuran dengan ketahanan sobek dan kekuatan tarik yang paling sesuai untuk aplikasi kertas kemasan. Proses yang digunakan untuk membuat pulp ampas tebu adalah proses acetosolv. Kertas serat campuran dibuat dengan variasi komposisi pulp ampas tebu dan pulp kertas koran dengan perbandingan 0:100, 10:90, 30:70, 50:50, dan 70:30. Selain itu, dilakukan juga variasi konsentrasi binder kulit pisang sebanyak 15, 25, 35, 45, dan $55 \mathrm{~g} / 4$ L. Hasil penelitian menunjukkan bahwa kertas serat campuran yang dihasilkan telah memenuhi standar kertas dasar kertas bungkus berlaminasi sesuai SNI 146519-2001. Kertas serat campuran yang dibuat dengan komposisi pulp ampas tebu 30\% dan konsentrasi binder $35 \mathrm{~g} / 4 \mathrm{~L}$ menghasilkan ketahanan sobek sebesar 4,018 KN/m dan kekuatan tarik sebesar 20,5 N walaupun gramatur kertas lebih besar dari standar yang ditetapkan.
\end{abstract}

Kata kunci: kertas serat campuran, pulp ampas tebu, binder kulit pisang, kertas kemasan

\begin{abstract}
Mixed fiber paper, also known as composite paper, is a paper made of two different fibers that aims to strengthen the paper. In this study, mixed fiber paper for packaging purposes was made by utilizing bagasse pulp and used newsprint pulp. As a binder, banana peel may be used since it contains starch and fiber. The objectives of this research were to study the effect of bagasse pulp composition and newsprint pulp, as well as to determine the mass amount of binder used in producing mixed fiber paper which has both tear resistance and tensile strength suitable for packaging paper. Mixed fiber paper was made by varying the ratio of bagasse pulp and newsprint pulp as follows: 0:100, 10:90, 30:70, 50:50, 70:30, 90:10, and 100:0. The study also carried out variation in binder concentration from banana skin flour of $15,25,35,45$, and $55 \mathrm{~g} / 4 \mathrm{~L}$. As results, mixed fiber papers produced in this study have met the requirement of Indonesia National Standard (SNI) of base paper for wrapping (SNI 14-6519-2001). Mixed fiber paper with composition of 30\% bagasse pulp and $35 \mathrm{~g} / 4 \mathrm{~L}$ banana peel binder concentration has tear resistance of $4,018 \mathrm{kN} / \mathrm{m}$ and tensile strength of $20,5 \mathrm{~N}$, although the grammage of all papers is above the standard.
\end{abstract}

Keywords: mixed fiber paper, bagasse pulp, banana peel binder, packaging paper

*korespondensi 


\section{Pendahuluan}

Saat ini penggunaan kertas di Indonesia semakin bertambah sehingga penggunaan kayu sebagai bahan baku pulp kertas juga meningkat (Pitakasari, 2011). Oleh karena itu, diperlukan bahan alternatif yang dapat digunakan untuk menggantikan peran kayu dalam pembuatan pulp kertas, salah satunya adalah ampas tebu.

Ampas tebu memiliki kandungan serat dan hemiselulosa yang tinggi, dimana kedua hal tersebut merupakan syarat utama dalam pembuatan kertas (Sudaryanto dkk., 2002; Witono dan Michaella, 2005; PaperOnWeb, 2010). Ada banyak penelitian yang telah dikembangkan untuk pembuatan pulp dan kertas dari ampas tebu, antara lain oleh Sudaryanto dkk. (2002) dan Antaresti dkk. (2004). Sudaryanto dkk. (2002) mempelajari proses pembuatan pulp dari ampas tebu dengan menggunakan jamur Fusarium solani dan Trichoderma viride, sedangkan Antaresti dkk. (2004) meneliti proses pembuatan pulp dari ampas tebu dengan proses organosolv menggunakan larutan pemasak asam asetat dan katalis asam sulfat.

Kertas serat campuran, atau seringkali dikenal dengan istilah kertas komposit, merupakan kertas yang terbuat dari campuran dua macam atau lebih pulp kertas dengan bahan lain, seperti polimer dan kertas bekas yang bertujuan untuk meningkatkan nilai guna kertas (Julianti dan Nurminah, 2006). Pembuatan kertas serat campuran merupakan salah satu cara alternatif pembuatan kertas yang akan membantu mengurangi limbah kertas dan terutama mengurangi penggunaan kayu untuk pembuatan kertas. Pada penelitian pembuatan kertas serat campuran ini, bahan baku yang digunakan adalah ampas tebu, sedangkan sebagai campurannya digunakan kertas koran bekas mengingat banyaknya produksi koran per hari yang tentunya akan menimbulkan masalah apabila kertasnya tidak didaur ulang. Metode yang digunakan dalam membuat pulp pada proses pembuatan kertas serat campuran ini adalah asetosolv, yaitu proses delignifikasi dengan menggunakan asam asetat (Vazquez dkk., 1997). Metode ini merupakan metode yang ramah lingkungan karena limbah lindi hitamnya mudah didaur ulang. Selain itu, asam asetat adalah salah satu pelarut organik yang tidak berbahaya bagi lingkungan.

Dalam pembuatan kertas serat campuran, umumnya digunakan binder untuk mengikat komponen-komponen penyusun kertas. Dalam penelitian ini, binder yang digunakan berasal dari bahan alami, yaitu kulit pisang. Kulit pisang mengandung pati yang merupakan salah satu komponen penting dari binder (Asuncion, 2003).

Tujuan penelitian ini adalah untuk mempelajari pengaruh perbandingan pulp ampas tebu dan pulp kertas koran serta konsentrasi binder dari kulit pisang sehingga dapat diperoleh kertas serat campuran dengan ketahanan sobek dan kekuatan tarik yang paling sesuai untuk diaplikasikan sebagai kertas kemasan.

\subsection{Kertas Kemasan}

Agar sesuai dengan aplikasinya sebagai bahan baku kertas kemasan, maka kualitas kertas serat campuran dalam penelitian ini diarahkan untuk dapat memenuhi Standar Nasional Indonesia (SNI 14-6519-2001) yaitu sebagai kertas dasar untuk kertas pembungkus berlaminasi plastik. Standar kertas yang diatur dalam SNI 14-6519-2001 dapat dilihat pada Tabel 1 (BSN, 2001). Arah mesin merupakan pengukuran yang dilakukan pada kertas yang searah dengan hasil cetakan kertas, sedangkan silang mesin menunjukkan pengukuran kertas yang dilakukan tegak lurus dari hasil cetakan kertas.

Tabel 1. Karakteristik Kertas Dasar untuk Kertas Pembungkus Berlaminasi Plastik Menurut SNI 14-6519-2001

\begin{tabular}{cccc}
\hline \multicolumn{2}{c}{ Karakteristik } & Satuan & Persyaratan \\
\hline $\begin{array}{c}\text { Gramatur } \\
\text { Tebal }\end{array}$ & $\begin{array}{c}\mathrm{g} / \mathrm{m}^{2} \\
\mathrm{~mm}\end{array}$ & $\begin{array}{c}70 \pm 2,8 \\
0,110-0,142\end{array}$ \\
\hline \multirow{4}{*}{ Kuat Tarik } & $\begin{array}{c}\text { Arah } \\
\text { Mesin }\end{array}$ & $\mathrm{kN} / \mathrm{m}$ & Min 1,96 \\
\cline { 2 - 4 } & $\begin{array}{c}\text { Silang } \\
\text { Mesin }\end{array}$ & $\mathrm{kN} / \mathrm{m}$ & Min 1,63 \\
\hline \multirow{2}{*}{$\begin{array}{c}\text { Ketahanan } \\
\text { Sobek }\end{array}$} & $\begin{array}{c}\text { Arah } \\
\text { Mesin }\end{array}$ & $\mathrm{mN}$ & Min 392 \\
\cline { 2 - 4 } & $\begin{array}{c}\text { Silang } \\
\text { Mesin }\end{array}$ & $\mathrm{mN}$ & Min 416 \\
\hline \multicolumn{2}{c}{$\begin{array}{c}\text { Porositas } \\
\text { Kekasaran, WS }\end{array}$} & $\begin{array}{c}\mathrm{mL} / \mathrm{menit} \\
\mathrm{mL} / \mathrm{menit}\end{array}$ & $\begin{array}{c}\text { Maks 1000 } \\
\text { Maks 1700 }\end{array}$ \\
\hline
\end{tabular}

\subsection{Ampas Tebu}

Ampas tebu, atau disebut juga dengan bagas, adalah hasil samping dari proses ekstraksi cairan tebu. Ampas tebu sebagian besar mengandung ligno-cellulose. Panjang seratnya antara 1,7-2 $\mathrm{mm}$ dengan diameter sekitar $20 \mu \mathrm{m}$, sehingga ampas tebu ini dapat memenuhi persyaratan untuk diolah menjadi 
papan-papan buatan. Serat bagas tidak dapat larut dalam air dan sebagian besar terdiri dari selulosa, pentosan, dan lignin. Hasil analisis serat bagas tercantum dalam Tabel 2 (Sudaryanto dkk., 2002).

\begin{tabular}{lc} 
Tabel 2. Komposisi Kimia Ampas Tebu \\
\hline \multicolumn{1}{c}{ Kandungan } & Kadar (\%) \\
\hline $\mathrm{Abu}$ & 3 \\
Lignin & 22 \\
Selulosa & 37 \\
Sari & 1 \\
Pentosan & 27 \\
$\mathrm{SiO}_{2}$ & 3 \\
\hline
\end{tabular}

\subsection{Proses Acetosolv}

Proses acetosolv dalam pengolahan pulp memiliki beberapa keunggulan, antara lain: bebas senyawa sulfur, daur ulang limbah dapat dilakukan hanya dengan metode penguapan dengan tingkat kemurnian yang cukup tinggi, dan nilai hasil daur ulangnya jauh lebih mahal dibanding dengan hasil daur ulang limbah kraft (Simanjutak, 1994). Aziz dan Sarkanen (1989) menguatkan pernyataan tersebut dengan mengatakan bahwa rendemen pulp lebih tinggi, pendauran lindi hitam dapat dilakukan dengan mudah, dapat diperoleh hasil samping berupa lignin dan furfural dengan kemurnian yang relatif tinggi, dan ekonomis dalam skala yang relatif kecil.

Dalam proses pembuatan pulp dengan metode acetosolv, ada banyak hal yang perlu diperhatikan, mulai dari suhu, waktu pemasakan, konsentrasi asam asetat dan juga konsentrasi katalis yang digunakan. Pada umumnya, proses pembuatan pulp dengan metode acetosolv dilakukan pada suhu $110^{\circ} \mathrm{C}$ selama 2-5 jam. Konsentrasi asam asetat yang digunakan sebesar 95\%. Katalis yang dipakai dalam proses pulping dengan metode acetosolv adalah asam klorida ( $\mathrm{HCl})$ sebanyak 0,01\% (Vazquez dkk., 1997).

\subsection{Binder}

Binder mempunyai pengaruh yang besar pada sifat akhir kertas. Fungsi binder antara lain bertindak sebagai pembawa pigmen, pengikat partikel pigmen menjadi satu, mengikat partikel pigmen dengan kertas, memberi sifat alir yang dibutuhkan dan mengontrol absorpsi tinta cetak selama proses cetak pada kertas (PaperOnWeb, 2010). Pati merupakan binder yang berasal dari bahan alam dan juga termasuk jenis perekat dalam. Pati mampu mengikat bahanbahan penyusun kertas untuk meningkatkan kualitas kertas. Pati ditambahkan dalam pembuatan pulp sebelum dibuat menjadi kertas. Pati akan meningkatkan jumlah kertas yang dihasilkan serta keelastisan kertas yang diproduksi. Pati mengisi pori kertas, menghaluskan permukaan kertas, dan mencegah tinta menyebar pada permukaan ketika kertas tersebut diitulis. Pati yang teroksidasi, asam dari modifikasi pati, dan kation dari pati biasa digunakan dalam proses pembuatan kertas, bersama dengan hidroksimetil yang dimodifikasi dan fosfat ester dari pati, untuk meningkatkan kekuatan dan ketebalan dari beberapa jenis kertas, seperti kertas untuk kalender dan kotak karton (Asuncion, 2003).

\subsection{Kulit Pisang}

Tanaman pisang merupakan salah satu jenis tanaman yang banyak tumbuh di daerah tropis. Kulit pisang mengandung banyak senyawa yang dapat dimanfaatkan. Kandungan dalam pisang dapat dilihat pada Tabel 3. Kandungan pati dalam kulit pisang cukup tinggi, yaitu 12,78\% (Emaga dkk., 2007). Dalam penelitian ini, pati yang terdapat dalam kulit pisang akan digunakan sebagai binder, sehingga mengurangi limbah dan menaikkan nilai ekonomis dari kulit pisang.

Tabel 3. Kandungan Senyawa Dalam Kulit Pisang

\begin{tabular}{lc}
\multicolumn{2}{c}{ Pisang } \\
\hline Senyawa & $\begin{array}{c}\text { Kandungan } \\
\text { (g/100 g berat kering) }\end{array}$ \\
\hline Protein & 8,6 \\
Lemak & 13,1 \\
Pati & 12,8 \\
Abu & 15,3 \\
Serat total & 50,3 \\
\hline
\end{tabular}

2. Metodologi

\subsection{Peralatan dan Bahan}

Perendaman kulit pisang dan kertas 96koran dilakukan dalam ember96. Pembuburan kertas 96koran dilakukan dengan blender. Pengecilan ukuran ampas tebu dilakukan dengan grinder. Proses delignifikasi dilakukan di dalam labu bundar 2 L dengan jaket pemanas dan dilengkapi dengan motor pengaduk, 96 termometer, dan bulb condenser. Proses penyaringan menggunakan vacuum pump dan corong Buchner. Kertas serat campuran dibuat 
dengan menggunakan cetakan kertas. Peralatan yang digunakan untuk pengujian adalah statif, klem, penjepit, wadah, dan beban pemberat.

Bahan yang digunakan dalam penelitian ini meliputi ampas tebu (kadar $\alpha$ selulosa $/$ KAS $=36,81 \%$, kadar air $=9,67 \%$, dan kadar abu $=6,16 \%$ ), kertas 97koran (kadar $\alpha$-selulosa $=83,63 \%$ ), serta kulit pisang (Musa 97paradisiaca $A B B$ ) dengan kadar pati $=10,11 \%$. Bahan kimia yang digunakan antara lain asam asetat, asam klorida, etanol teknis, dan natrium tiosulfat pentahidrat. Ampas tebu dan kertas 97koran sebagai bahan baku kertas serat campuran, sedangkan kulit pisang sebagai bahan baku binder kertas. Asam asetat digunakan sebagai larutan pemasak dalam proses delignifikasi dengan asam klorida sebagai katalis. Etanol digunakan dalam proses bleaching tinta kertas koran bekas, sementara natrium tiosulfat pentahidrat digunakan dalam proses pembuatan binder.

\subsection{Prosedur Kerja}

Tahapan penelitian yang dilakukan adalah sebagai berikut: pembuatan binder dari kulit pisang, pembuatan pulp ampas tebu, pembuatan pulp kertas koran, serta pembuatan dan pengujian kertas serat campuran.

Pembuatan binder kulit pisang dilakukan dengan merendam kulit pisang kepok yang telah dipotong kecil dalam larutan natrium tiosulfat. Kulit pisang kemudian dikeringkan dan ditumbuk hingga halus (Direktorat Pengolahan dan Pemasaran Hasil Hortikultura, 2004).

Pembuatan pulp ampas tebu dilakukan dengan mencuci ampas tebu terdahulu dan dijemur hingga kering. Ampas tebu kemudian digiling hingga halus. Serbuk ampas tebu dimasukkan dalam labu ukur 2 L sebanyak $60 \mathrm{~g}$ bersama dengan asam asetat sebanyak $600 \mathrm{~mL}$ dan asam klorida 0,01\%. Pemasakan ampas tebu dilakukan pada suhu maksimum $110^{\circ} \mathrm{C}$ dengan tekanan yang terjadi pada suhu tersebut. Pengadukan dilakukan dengan kecepatan 900 rpm selama 2 jam (Vazquez dkk., 1997). Pulp ampas tebu yang dihasilkan disaring dan dibilas dengan aquades. Pulp kemudian direndam dalam etanol selama 24 jam, lalu disaring dan dikeringkan.

Pembuatan pulp kertas koran dilakukan dengan merendam kertas koran dalam aquades dan membuburkan kertas koran terlebih dahulu. Setelah itu, kertas koran direndam dalam etanol untuk proses bleaching atau penghilangan tinta. Pulp kertas koran kemudian disaring dan dikeringkan.

Pembuatan kertas serat campuran dilakukan dengan mencampur pulp ampas tebu dan pulp kertas koran dengan komposisi massa pulp ampas tebu terhadap pulp kertas koran sebagai berikut: 0, 10, 30, 50, dan 70\%. Campuran pulp kemudian dicampur dengan menggunakan blender, sementara itu binder kulit pisang dilarutkan dalam air hangat sebanyak $400 \mathrm{~mL}$. Larutan binder kulit pisang kemudian dicampur ke dalam bubur pulp, kemudian diencerkan hingga volume $4 \mathrm{~L}$. Dilakukan variasi terhadap konsentrasi binder, yaitu 15, 25, 35, 45, dan 55 g/4 L. Bubur pulp lalu dicetak dengan menggunakan cetakan kertas dan dikeringkan pada suhu ruang sehingga didapatkan lembaran kertas.

\subsection{Pengujian}

Pengujian kertas serat campuran dilakukan dengan menentukan gramatur, kuat tarik dan ketahanan sobek kertas. Pengujian gramatur dilakukan menurut SNI ISO:538-2010 (BSN, 2010). Pengujian kuat tarik kertas dilakukan dengan menggunakan modifikasi dari SNI 14-0437-2008 (BSN, 2008). Pengujian ketahanan sobek dilakukan dengan metode Elmendorf yang telah dimodifikasi dari SNI 14-0436-2009 (BSN, 2009).

\section{Hasil dan Pembahasan}

\subsection{Gramatur Kertas pada Berbagai Variasi Komposisi Pulp dan Konsentrasi Binder}

Dari proses pembuatan kertas serat campuran didapatkan gramatur kertas untuk berbagai variasi komposisi pulp (pulp ampas tebu : pulp kertas koran) dan konsentrasi binder dari kulit pisang. Data gramatur kertas dapat dilihat pada Gambar 1. 


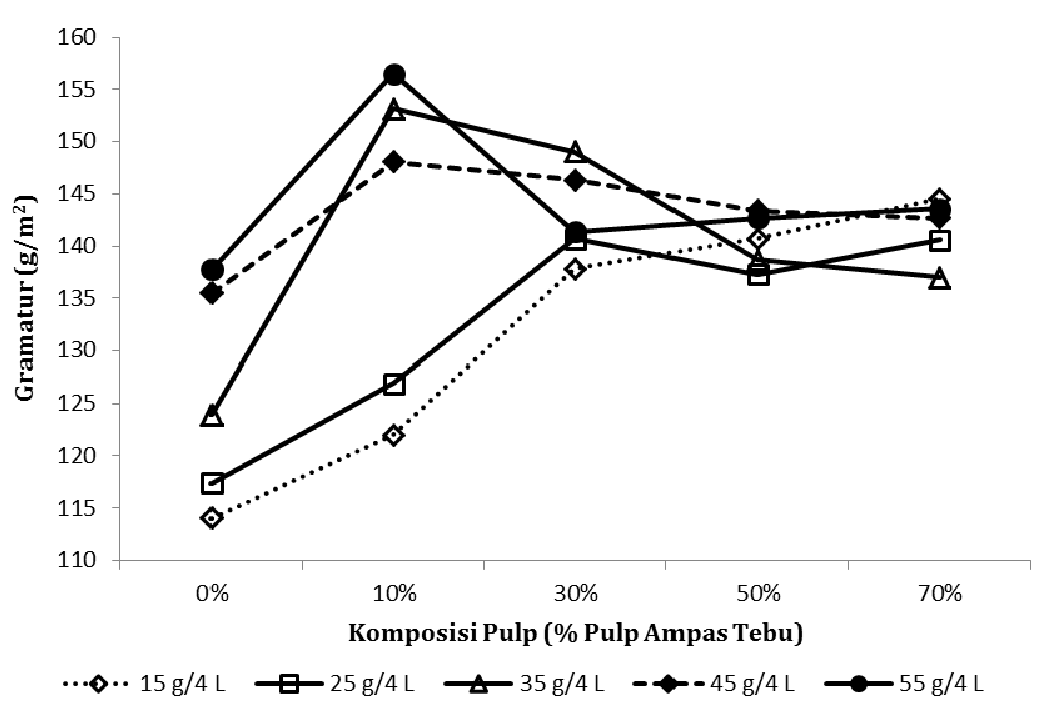

Gambar 1. Gramatur kertas serat campuran pada berbagai komposisi pulp

Gramatur merupakan massa kertas dari suatu satuan luas tertentu (BSN, 2010). Dari data yang diperoleh, gramatur kertas serat campuran bervariasi antara 114,0333 $156,5000 \mathrm{~g} / \mathrm{m}^{2}$. Gramatur kertas yang bervariasi tersebut disebabkan oleh proses pencetakan kertas yang masih manual sehingga sulit didapatkan gramatur kertas yang konstan. Selain itu, gramatur kertas juga tidak memenuhi SNI 14-6519-2001 untuk kertas dasar kertas bungkus berlaminasi yang memiliki standar sebesar $70 \pm 2,8 \mathrm{~g} / \mathrm{m}^{2}$ (BSN, 2001) serta tidak dapat menghasilkan kertas dalam lembaran tipis karena keterbatasan dalam proses pencetakan. Hal ini berbeda dengan dunia industri, dimana pencetakan kertas dapat diatur melalui tekanan dan debit tangki keluaran buburan kertas pada alat yang digunakan sehingga kertas dapat dicetak sesuai dengan standar yang ada dan dihasilkan gramatur yang konstan (Julianti dan Nurminah, 2006).

\subsection{Pengaruh Komposisi Pulp dan Konsentrasi Binder Terhadap Ketahanan Sobek dan Kuat Tarik Kertas}

Hasil ketahanan sobek dan kuat tarik kertas serat campuran bervariasi pada berbagai komposisi pulp dan konsentrasi binder dari kulit pisang. Hasil penelitian ketahanan sobek dan kuat tarik kertas serat campuran dapat dilihat pada Gambar 2 dan Gambar 3, secara berurutan.

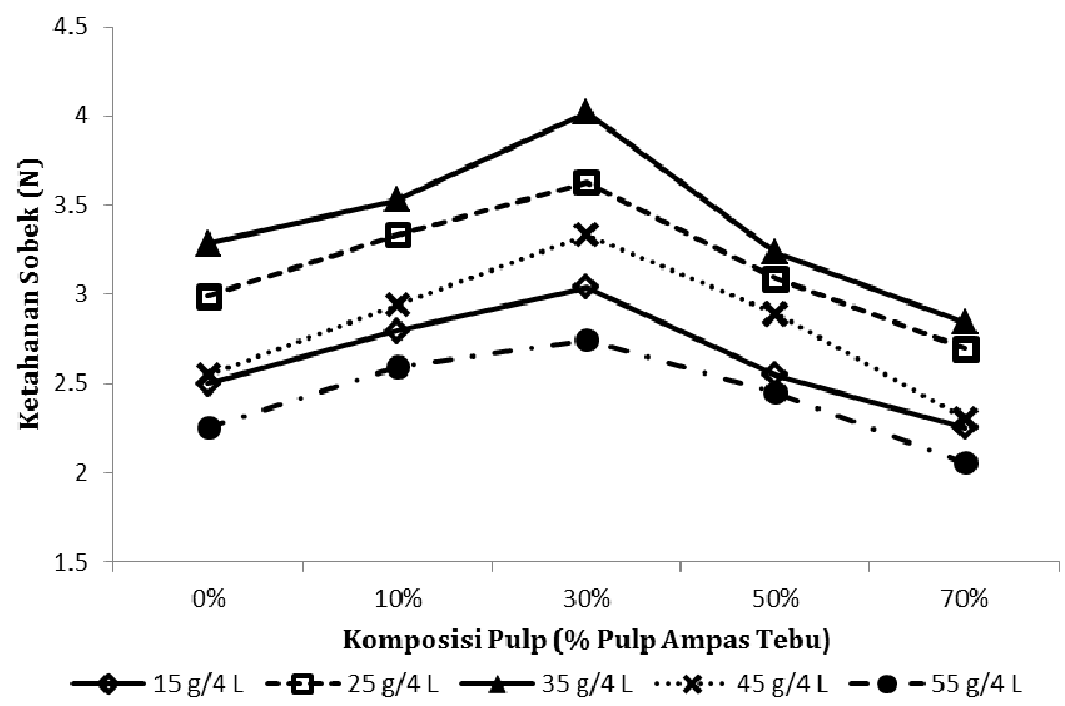

Gambar 2. Hasil uji ketahanan sobek kertas serat campuran pada berbagai komposisi pulp 


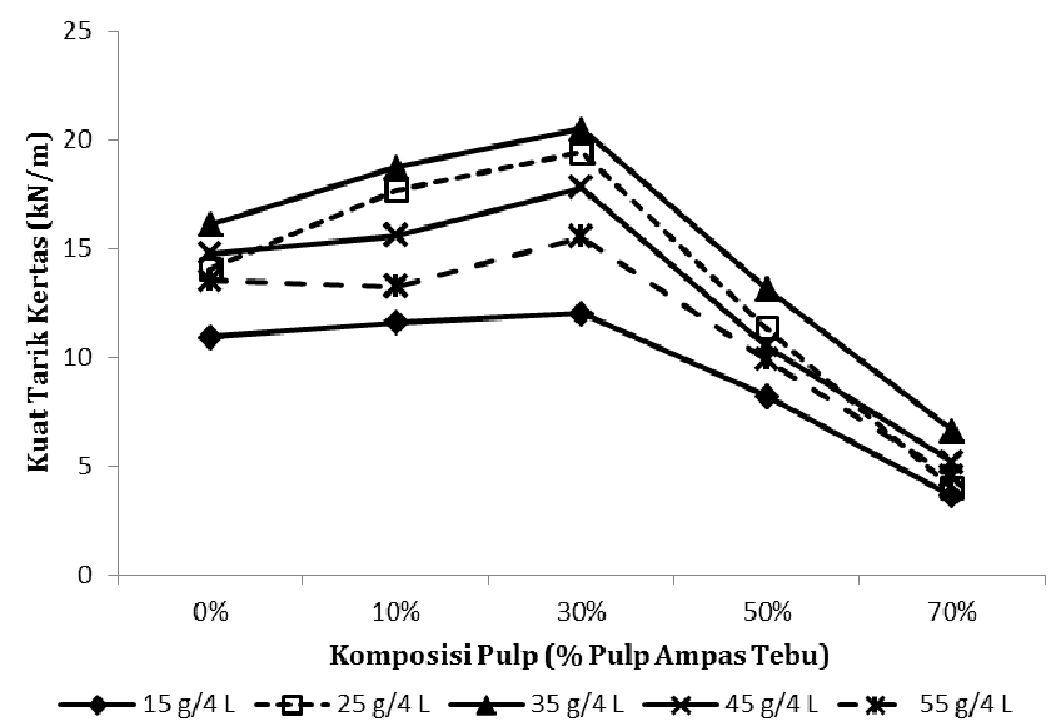

\section{Gambar 3. Hasil uji kuat tarik kertas serat campuran pada berbagai komposisi pulp}

Dari Gambar 2 dan Gambar 3, dapat dillihat bahwa ketahanan sobek dan kuat tarik kertas paling maksimal didapatkan pada saat komposisi pulp ampas tebu 30\%. Hal ini disebabkan karena pada kertas dengan komposisi pulp ampas tebu terlalu besar (> 30\%), kandungan serat pendek menjadi semakin banyak dibandingkan dengan serat panjang yang berasal dari pulp kertas koran sehingga kertas menjadi lebih rapuh (Stuart, 1996). Pada kertas dengan komposisi ampas tebu terlalu kecil $(<30 \%)$, kertas juga menjadi lebih rapuh karena kandungan pulp kertas koran menjadi semakin banyak dibandingkan dengan pulp ampas tebu. Serat recycle seperti kertas koran mempunyai low tensile strength karena serat telah mengalami proses mekanis yang singkat tetapi berulang menyebabkan rusaknya serat (Kelly, 1989).

Hasil penelitian menunjukkan bahwa ketahanan sobek dan kuat tarik kertas paling besar pada saat konsentrasi binder sebanyak 35 g. Hal ini disebabkan karena pada saat konsentrasi binder terlalu besar (>35 g), kandungan pati yang terlarut terlalu tinggi, sehingga kertas menjadi lebih keras dan juga getas (PaperOnWeb, 2010). Binder yang digunakan adalah pati dari kulit pisang dimana kandungan amilopektinnya lebih tinggi daripada amilosa $(76-81 \%$ dan 19 $24 \%$, secara berurutan). Semakin tinggi kandungan amilopektin maka tensile strength-nya semakin rendah (Kaplan, 1998). Keadaan kertas yang keras dan getas inilah yang menyebabkan kertas menjadi mudah disobek. Pada konsentrasi binder terlalu rendah $(<35 \mathrm{~g})$, binder pati yang terlarut lebih sedikit, akibatnya pati tidak dapat mengikat selulosa dengan baik dan kertas menjadi lebih rapuh (PaperOnWeb, 2010).

Hasil kertas serat campuran yang didapatkan semua memenuhi standar ketahanan sobek dan kuat tarik menurut SNI 14-6519-2001 untuk kertas dasar kertas bungkus berlaminasi yang memiliki standar minimum 0,416 $\mathrm{N}$ untuk ketahanan sobek dan 1,63 kN/m untuk kuat tarik kertas (BSN, 2001).

\section{Kesimpulan}

Ketahanan sobek dan kuat tarik kertas makin meningkat seiring dengan peningkatan komposisi pulp ampas tebu terhadap pulp kertas koran hingga ketahanan maksimum, yaitu $4,0180 \mathrm{~N}$ pada ketahanan sobek dan $20,5 \mathrm{kN} / \mathrm{m}$ pada kuat tarik untuk perbandingan 30:70, dan kemudian menurun menjadi 2,8420 $\mathrm{N}$ untuk ketahanan sobek dan 6,62 kN/m untuk kuat tarik. Ketahanan sobek kertas serat campuran dari ampas tebu telah memenuhi SNI 14-6519-2001 yang merupakan standar kertas dasar kertas bungkus berlaminasi. Ketahanan sobek dan kuat tarik kertas juga meningkat seiring dengan peningkatan penggunaan binder tepung kulit pisang hingga batas maksimum, yaitu 4,0180 N pada ketahanan sobek dan $20,5 \mathrm{kN} / \mathrm{m}$ pada kuat tarik untuk konsentrasi binder $35 \mathrm{~g} / 4 \mathrm{~L}$, kemudian menurun. 


\section{Daftar Pustaka}

Antaresti; Christina, N.; Selviana, E.; Indrawati, M.; Yosanto, Organosolv dan Proses Biokimia sebagai Alternatif Proses Pulping yang Ramah Lingkungan, Prosiding Seminar Nasional Fundamental dan Aplikasi Teknik Kimia, Surabaya, 15 November 2004.

Asuncion, J., The Complete Book of Paper Making, Lark Books: New York, 2003; hal. 29.

Aziz, S.; Sarkanen, K., Organosolv pulping - A review, TAPPI Journal, 1989, 72(3), 169-175.

BSN, Cara Uji Kekuatan tarik dan Daya Regang lembaran Pulp, Kertas dan Karton (Metode Kecepatan Pembebanan Tetap, SNI 14-0437-2008, 2008.

BSN, Kertas: Cara Uji Ketahanan Sobek Metode Elmendorf, SNI 14-0436-2009, 2009.

BSN, Kertas dan Karton - Cara Uji Gramatur, SNI ISO 536:2010, 2010.

BSN, Kertas Dasar untuk Kertas Pembungkus Berlaminasi Plastik, SNI 14-6519-2001, 2001.

Direktorat Pengolahan dan Pemasaran Hasil Hortikultura, Cara Membuat Tepung Pisang, Buletin Teknopro Hortikultura, 2004.

Emaga, T. H.,; Andrianaivo, R. H.; Wathelet, B.; Tchango, J. T.; Paquot, M., Effects of the stage of maturation and varieties on the chemical composition of banana and plantain peels, Food Chemistry, 2007, 103(2), 590600, 2007.

Julianti, E.; Nurminah, M., Teknologi Pengemasan, Bahan kuliah terbuka Opencourseware, Universitas Sumatera Utara, 2006.

Kaplan, D. L., Biopolymers from Renewable Resources, Springer-Verlag Berlin Heidelberg: New York, 1998; hal. 39, 1998.

Kelly, A., Concise Encyclopedia of Composite Materials, Pergamon Press: England, 1989; hal. 217.
Nguyen, X. T., Recycling Waste Cellulosic Material with Sodium Sulphide Digestion, U.S. Patent 5,147,503, 15 Sept 1992.

PaperOnWeb, http://paperonweb.com/ wood.htm, (akses 20 September 2010).

Pitakasari, A. R., Perusahaan Tak Cemas Krisis di Barat, Kebutuhan Pulp dan Kertas Asia Menguat, Republika Online, 15 Desember 2011.

http://www.republika.co.id/berita/ekonomi /bisnis/11/12/15/lw94xx-perusahaan-takcemas-krisis-di-barat-kebutuhan-pulp-dankertas-asia-menguat (akses 24 Juni 2012).

Simanjutak, H. M., Mempelajari Pengaruh Komposisi Larutan Pemasak dan Suhu Pemasakan pada Pengolahan Pulp Acetosolv Kayu Eucalyptus Deglupta, Skripsi, Institut Pertanian Bogor, Agustus 1994.

Stuart, R. C., Development TMP fiber and quality of pulp, Appita, 1996, 49(5), 197-210.

Sudaryanto, Y.; Antaresti; Wibowo, H., Biopulping Ampas Tebu Menggunakan Trichoderma viride dan Fusarium solani, Prosiding Seminar Nasional Fundamental dan Aplikasi Teknik Kimia, Surabaya, 30 September 2002; hal. 163-171.

Vazquez, G.; Antorrena, G.; Gonzalez, J.; Freire, S.; Lopez, S., Acetosolv pulping of pine wood. kinetic modelling of lignin solubilization and condensation, Bioresource Technology, 1997, 59(2-3), 121-127.

Witono, J. R.; Michaella, Pengaruh Pencampuran Serat Pelepah Pisang dan Serat Kertas Koran Bekas terhadap Kualitas Kertas yang Dihasilkan, Prosiding Seminar Nasional Fundamental dan Aplikasi Teknik Kimia, Surabaya, 27 Juni 2005; hal. 108-113.

Yung, B. S.; Jeon, Y.; Shin, Y. C.; Kim, D., Effect of mechanical impact treatment on fibre morphology and hand-sheet properties, Appita, 2002, 55(6), 475-479. 